\title{
Dynamics of Sclerotium rolfsii as influenced by different crop rhizosphere and microbial community
}

\author{
K. $\operatorname{Ray}^{1}$, K. Sen ${ }^{1}$, P.P. Ghosh ${ }^{2}$, A. Roy Barman ${ }^{1}$, R. Mandal ${ }^{1}$, M. De Roy ${ }^{3}$ and S. Dutta ${ }^{\text {* }}$ \\ ${ }^{1}$ Department of Plant Pathology, BCKV, Mohanpur, Nadia (West Bengal), INDIA \\ ${ }^{2}$ Rice Research Station, Bankura, (West Bengal), INDIA \\ ${ }^{3}$ Soil Testing Laboratry, Berhampore (West Bengal), INDIA \\ *Corresponding author. E-mail: subratadutta1972@gmail.com
}

Received: October 30, 2016; Revised received: March 5, 2017; Accepted: July 31, 2017

\begin{abstract}
This study was carried out with the aim of evaluating pathogenicity of Sclerotium rolfsii to different crops influenced by different crop rhizosphere microbes and their population dynamics. Napier was found to be non-preferred host against $S$. rolfsii pathogen. Among the seven tested crops in micro-plot study, highest level of induction of sclerotial population was observed in groundnut and cow peas (21.81 and 20.06 numbers of sclerotia /100 g of soil, respectively), whereas, reduction in sclerotial number was observed in napier, maize and sorghum plots. S. rolfsii induced damping off was found to be significantly positively correlated with average sclerotial population irrespective of plant cover even at $1 \%$ level of significance $(r=0.985)$ and among the microbiological parameters, FDA was found to be significantly negatively correlated with damping off disease percentage at $5 \%$ level of significance $(r=-0.830)$. Therefore, Napier may be the potential crop to be incorporated in the sequence of rice/vegetable based cropping system in West Bengal for management of this dreaded pathogen.
\end{abstract}

Keywords: Conducive soils, Crop rhizosphere, FDA, Soil borne pathogens, Suppressive soils

\section{INTRODUCTION}

Soil-borne diseases are the main factors responsible for lowering the production of many crops compared to seed-borne or air-borne diseases and account for $10-20 \%$ of yield losses annually (USDA, 2003). Many soil borne plant pathogens produce resting structures freely or embedded in the infected plant debris in soil or above-ground parts and survive for many years. Management of soil-borne plant pathogens is difficult due to hidden status of the causal agents, low inherent level of resistance of crop cultivars against such diseases, existence of high level genetic variability and wide host range of the pathogens, their ability to survive in soil for a long time due to durable resting structure (such as melanized sclerotia, mycelia, spore, etc.) and complex interaction with crop rhizosphere, soil environment and microbiota. The rhizosphere is an environment that the plant itself helps to create and where pathogenic and beneficial microorganisms constitute a major influential force on plant growth and health (Lynch and Whipps, 1990). Thus, the complex interaction of soil environmental factors, crops and their rhizo-deposition, soil physico-chemical and biological properties ultimately direct the soil towards soil-borne plant pathogens supressive and conduciveness (van Agtmaal, 2015).

Sclerotium rolfsii Sacc. (telomorph: Athelia rolfsii (Cruzi) Tu and Kimbrough) is a widespread soil borne pathogen in vegetable production areas mostly in the tropical and subtropical regions where soil temperature prevails around $30^{\circ} \mathrm{C}$ (Harlapur, 1988). It causes Southern blight, a disease which affects more than 500 plant species in over 100 plant families, the most common species belonging to legumes, crucifers, cucurbits and crops of solanaceous family. S. rolfsii produces sclerotia on the infected portions of the plant near the soil-line. The sclerotia can survive in the soil from a few months to several years, depending on environmental conditions (Xu et al., 2008) and are the primary source of inoculum for disease development. After germination, S. rolfsii hyphae produce oxalic acid and pectinolytic and cellulolytic enzymes which kill and disintegrate host tissues, starting a new infection (Le, 2011). It has been reported that the pathogen caused $25 \%$ seedling mortality in groundnut cultivar JL-24 (Ingale and Mayee, 1986) and over 25\% yield loss (Mayee and Datar, 1988), 30\% crop loss on Tomato (Thiribhubanamala et al,1999), 53.4\% dry seed yield loss of cowpea (Fery and Dukes, 2002), 40$50 \%$ plant mortality of Crossandra (Harinath Naidu, 2000) and 5-20\% crop loss of peppermint (Singh and Singh, 2004). Sclerotia is the primary source of inoculums in soil and the pathogen mainly penetrated plants through the plant parts in contact with soil including fruits instead of roots. Soil temperature of 25 $-30^{\circ} \mathrm{C}$ and soil moisture $90 \%$ play major role in disease 
development (Gupta et al., 2002).

Methods employed to manage $S$. rolfsii are fungicides application, solarization, and use of antagonistic microorganisms, deep ploughing, crop rotation, and incorporation of organic and inorganic residues. Owing to its broad host range as well as worldwide distribution, management of necrotrophic pathogen Sclerotium rolfsii is not effective through any single approach strategy (Kumar et al., 2013). Despite the ability of $S$. rolfsii to survive for long periods in the soil as saprophyte on plant debris or in the form of sclerotia in the absence of host plants (Garren, 1961), there are reports of the beneficial use of crop rotation in combating the menace of the pathogen. Crops in the rotation should be selected in such a way that the probabilities for pathogens to infect and colonize the host are minimized. Population of soil borne pathogens are known to diminish, to relatively harmless levels if various plant species are carefully arranged in a cropping sequence for reasonable periods of time (Cook and Baker, 1983). The incorporation of the residues of various legume crops (black beans, cowpea, lupins and hairy vetch) resulted in the highest sclerotia densities and various grasses (sudangrass, foxtail millet, and in some cases oat and wheat) as well as sunhemp resulted in a reduction of sclerotia in the soil, however, an increase in inoculum density does not necessarily increase the inoculum potential (Ferguson and Shew, 2001). In general, crops and green manures should be screened for preference of $S$. rolfsii and incorporated in rotation so that soil-borne effective population of the pathogen is minimized as primary inoculum which eventually reduce disease incidence in long run. Survival, population build up, successful parasitic relationship and rate of spread of Sclerotium rolfsii in soil-plant system depend on different types of crops in sequence, rhizosphere microbial diversities, soil physico-chemical and biological characteristics and abiotic stress factors like soil moisture and temperature. The thorough understanding of these factors with special emphasis on influence of different rotational crops for declining of $S$. rolfsii population in rice/vegetable based cropping system of West Bengal is of urgent need for formulating of holistic approach for $S$. rolfsii diseases management.

Therefore, the present investigation was framed to unveil the relationship of various microbial parameters influenced by different crop rhizosphere with the sclerotial dynamics, pathogenicity and suppression of over seasoning structure of $S$. rolfsii and to identify suitable crop component that can be incorporated in the sequence of the predominant rice/vegetable based cropping system to adopt the bio-intensive management strategy against the dreaded pathogen.

\section{MATERIALS AND METHODS}

Collection, isolation and mass multiplication of test pathogen: Sclerotium rolfsii infected tomato plants were collected from farmer's fields near Bidhan Chandra Krishi Viswavidyalaya, Mohanpur, Nadia, West Bengal. The pathogen was isolated by picking individual sclerotia from infected Tomato surface sterilized with $0.25 \%$ Sodium hypochlorite for approximately 2.5 minutes followed by three washing with sterilized distilled water (Utkhede and Rahe, 1979). The sclerotia were then placed into Potato Dextrose Agar (PDA) media in Petri dishes and incubated at $28 \pm 2^{\circ} \mathrm{C}$. Sclerotia formed after 10 days were picked up without mycelia air dried and pourded into sterile PP pakets and kept at $4^{\circ} \mathrm{C}$ for further use.

Mass multiplication of the fungus was done using rice straw bits $(2-3 \mathrm{~cm})$. Rice straw bits $(500 \mathrm{~g})$ were soaked into tap water for 1 hour followed by removal of extra water by pressing. The wet straw bits were then poured equally into ten $500 \mathrm{ml}$ clean conical flasks followed by sterilization for $20 \mathrm{~min}$ at 15 psi. The actively growing entire mycelial mat on a $9 \mathrm{~cm}$ PDA plate along with medium was aseptically poured into a conical flask containing sterile straw bits and ten such flasks were put into incubator at $28 \pm 2^{\circ} \mathrm{C}$ for 15 days. After 15 days fully colonized rice straw bits with large number of sclerotia were air dried (exposed to natural air contaminants) used for surface inoculation in the micro-plots. Mature sclerotia from the rice straw bits were separated and were placed on to PDA (10 sclerotia per plate with three replication) and assayed for viability and found the viability were near $100 \%$.

Experimental details: To identify the suppressive / conducive crops which influence the $S$. rolfsii disease severity, the micro-plot $(2 \mathrm{~m} \times 1 \mathrm{~m})$ experiment was conducted under polyhouse condition at C-Block research farm, Bidhan Chandra Krishi Viswavidyalaya, Kalyani, Nadia, West Bengal, following a randomized block design (RBD) with seven treatments and three replications. The treatments consisedt of seven different crop viz. Amaranthus, Groundnut, Cowpea, Ricebean, Sorghum, Maize and Napier. The upper layer of soil of the micro plots was infested with fully colonized dried straw bits (10 g/microplots). The initial (just before sowing) and subsequent sclerotial population was determined starting from 10 days after infestation at 20 days interval upto 80 days after sowing by wet sieving method (Leach and Davey, 1938 ) and viability was determined in water agar plate at $30 \pm 2^{\circ} \mathrm{C}$. Sowing of seeds of respective crops was done 10 days after infestation.

Microbiological factors like fluorescein diacetate (FDA) hydrolysis assay, total bacteria, total fungus, fluorescent Pseudomonads, Actinomycetes and Trichoderma population was enumerated at similar intervals throughout the cropping period. For FDA hydrolysis assay, the topsoil was sifted through a sieve ( $2 \mathrm{~mm}$ mesh) and either used fresh or stored at $5^{\circ} \mathrm{C}$ before being used. Determination of FDA hydrolysis 
was done according to Schnurer and Rosswall (1982) and the amount of FDA hydrolyzed was measured as absorbance at $490 \mathrm{~nm}$ using a spectrophotometer. Total fungi and total bacteria were isolated by dilution plate technique from $1 \mathrm{~g}$ air dried soil. Serial dilution of $1: 10^{3}$ and $1: 10^{6}$ was prepared in sterilized water and plated on peptone dextrose rose bengal agar medium for total fungi and on soil extract agar medium for total bacteria, respectively (Devi and Chettry, 2012). Similarly, fluorescent Pseudomonads, Actinomycetes and Trichoderma population was determined using King's B (Ghosh et al., 2015), Starch Casein Agar (SCA) (Jeffrey, 2008) and Trichoderma selective medium (Elad and Chet, 1983), respectively, at 1:10 $1: 10^{5}$, and $1: 10^{2}$ serial dilutions. One $\mathrm{ml}$ each of soil suspension of desired dilution was placed in each sterilized Petri plate and $20 \mathrm{ml}$ of cooled molten medium was poured in the same plate and gently rotated horizontally to get uniform distribution of the suspension in medium. These plates were incubated at $28 \pm 1^{\circ} \mathrm{C}$ for four days in three replications. Identification was done by using a cascade of morpho-physiological and biochemical tests along with relevant literature and keys. In all the cases fungal and bacterial colonies were counted and calculated in colony forming units per gram of soil ( $\left.\mathrm{cfu}^{-1}\right)$.

The disease incidence (DI\%) were estimated at 20, 40, 60 and 80 days after sowing by means of the percentage of number of infected plant to total number of plants per microplot. The Area Under Disease Progress Curve was determined using following formula (Dasgupta, 1988): , where, $S_{i}$ is the disease severity at time $T_{i}$ of $i^{\text {th }}$ observation.

$A U D P C=\frac{1}{2} \sum_{i=1}^{k}\left(S_{i+1}+S_{i}\right) \times\left(T_{i+1}-T_{i}\right)$

Data analysis: The effect size of treatments and their temporal variation and respective interactions were analysed by means of ANOVA. The relationship between different microbiological factors like FDA, Total bacteria, Total fungus, Pseudomonas, Actinomycetes, Trichoderma in respect to various crops rhizosphere and their susceptibility / tolerance against $S$. rolfsii was done by Pearson's correlation and stepwise multiple regression studies using SPSS v23 software package. Influence of sclerotial production and soil microbiological parameters of seven different crops having difference in susceptibility against $S$. rolfsii were estimated and put to regression as independent variable and AUDPC, sclerotial population, dead sclerotia and sclerotial decay percentage as dependent variable.

\section{RESULTS AND DISCUSSION}

Effect of different crops' rhizosphere on $S$. rolfsii under micro-plot condition:

Disease severity: From this experiment, it is evident

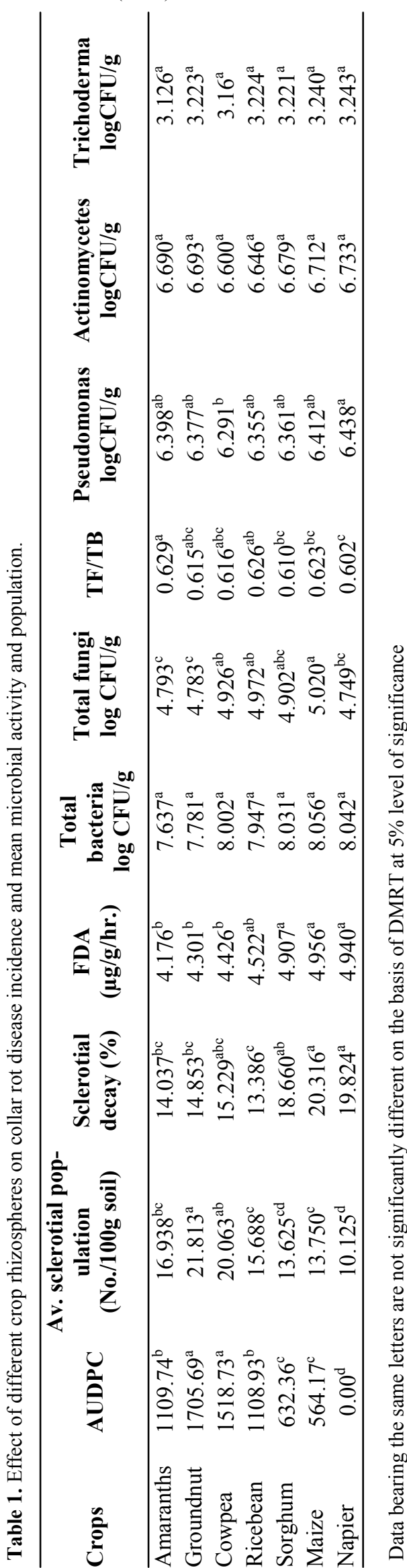


Table 2. Correlation matrix of $S$. rolfsii induced damping off, sclerotial population and sclerotial decay with microbiological parameters.

\begin{tabular}{lccc}
\hline \multicolumn{1}{c}{ Attributes } & Sclerotial nos. & Sclerotial Decay \% & AUDPC \\
\hline Av. Sclerotial population nos./100g soil & 1 & & \\
Sclerotial Decay \% & -0.708 & 1 & \\
AUDPC & $0.985^{* *}$ & $-0.796^{*}$ & 1 \\
FDA hydrolysis $(\mu \mathrm{g} / \mathrm{g} / \mathrm{hr})$ & $-0.806^{*}$ & $0.906^{* *}$ & $-0.830^{*}$ \\
Total Bacteria $\log \mathrm{CFU} / \mathrm{g}$ soil at $40 \mathrm{DAS}$ & $-0.871^{*}$ & $0.781^{*}$ & $-0.844^{*}$ \\
Fluorescent $\mathrm{pseudomonads} \log \mathrm{CFU} / \mathrm{g}$ soil at $60 \mathrm{DAS}$ & $-0.793^{*}$ & 0.526 & $-0.779^{*}$ \\
\hline
\end{tabular}

*Correlation is significant at the $5 \%$ level (2-tailed); ** Correlation is significant at the $1 \%$ level (2-tailed); AUDPC $=$ area under disease progress curve; DAS = Days after sowing; $\mathrm{CFU}=$ Colony forming unit.

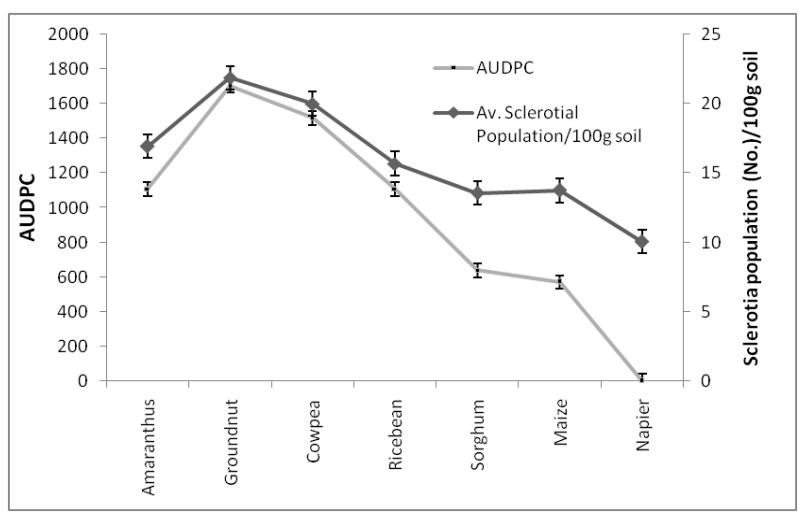

Fig. 1. Relationship between AUDPC and average sclerotial population in soil. Error bar represents standard error of mean.

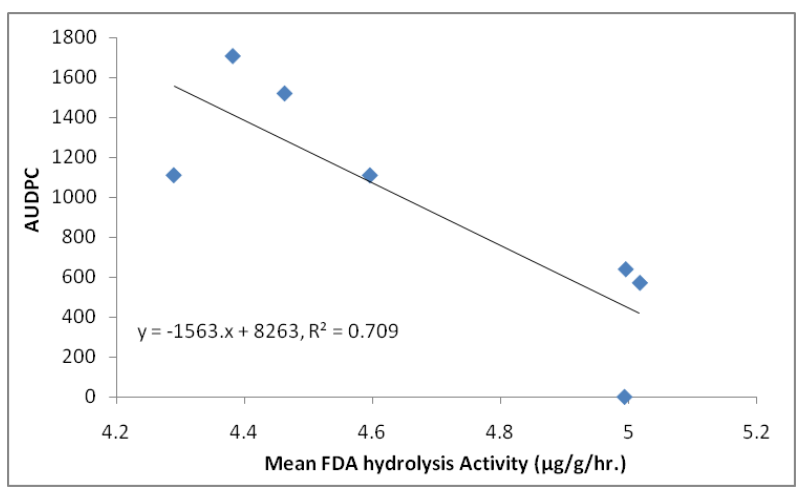

Fig. 2. Relationship of FDA hydrolysis activity and AUDPC.

that among the seven crop species, six were susceptible at varied level (AUDPC ranges from 564 to 1706) to the pathogen, except the napier (Table 1). Groundnut showed the highest AUDPC (1705.69) followed by cowpea (1518.73), ricebean (1108.39) and amaranthus (1109.74). Therefore, groundnut and cowpea were highly susceptible, amaranthus and ricebean were categorized into moderate susceptible and sorghum and maize (AUDPC 632.36 and 564.17) as tolerant against tomato isolate of $S$. rolfsii. Napier was found to be immune to the pathogen and therefore, can be incorporated in cropping sequence and mixed crop approach for management of this dreaded pathogen. The tem-

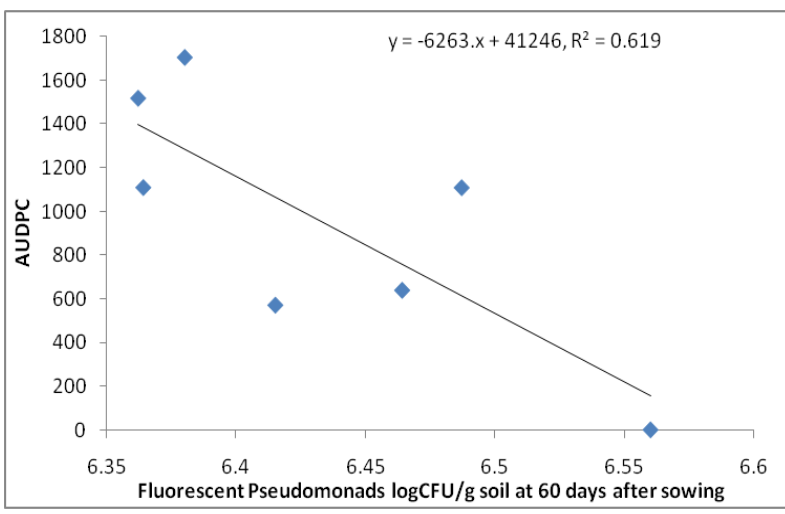

Fig. 3. Relationship of fluorescent pseudomonads population and $A U D P C$.

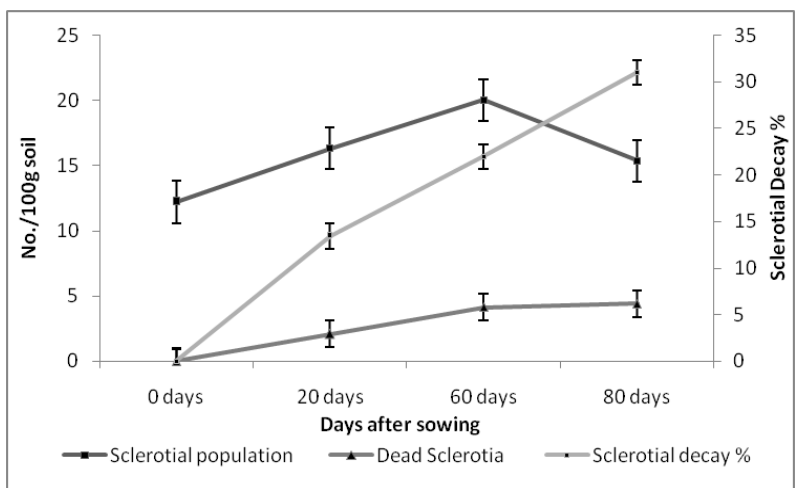

Fig. 4. Sclerotial population dynamics [error bar represents $S E(m) \pm]$.

poral dynamics of the disease severity sowed that irrespective of crop species, DI\% increased significantly at a rate of $3.2 \%$ per day upto 40 days after sowing while after that the rate of increase was negligible and insignificant. Therefore, it can be concluded that crop age has a significant effect on pathogenicity and/or disease development of all the crops under study. The AUDPCs of different crops is significantly positively correlated with average sclerotial population in the soil $(\mathrm{r}=0.985)$ (Fig. 1 and Table 2) and negatively correlated with sclerotial decay percentage $(r=-0.796)$, FDA hydrolysis at 40 DAS onwards $(\mathrm{r}=-0.872$, - 


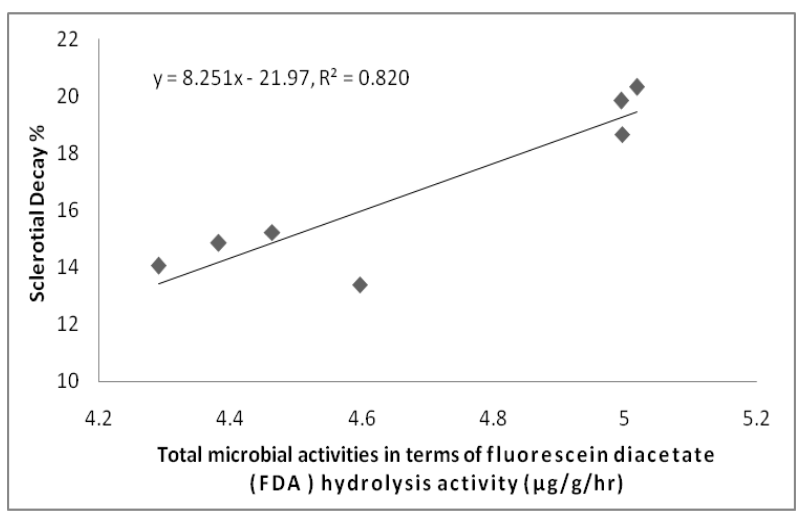

Fig. 5. Relationship with FDA and Sclerotial decay\%.

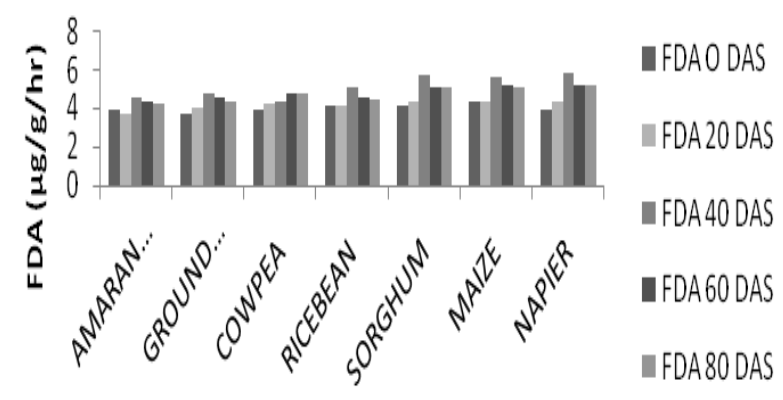

Fig.7. Dynamics of FDA hydrolysis during crop growth stages of different crops.

0.777, -0.789 and -0.830) (Fig.2, Table 2) and AUDPC with fluorescent pseudomonads population at 60 days after sowing $(\mathrm{r}=-0.779)$ (Fig. 3) in the rhizosphere of the respective crops. It is evident from the present study that a crop age dependent rhizospheric stimulation effect playing significant role to influence the microbial activity of the soil that suppress the disease development or new infection. This finding indeed explained the negligible rate of disease increase after 40 days from sowing. Therefore, conducive/ suppressive effect of root rhizosphere is definitely delegated indirectly by means of influencing the rhizosphere microbial activity against pathogenic invasion of soil borne inoculum.

Sclerotial population: The sclerotial population in the soil varied significantly among the seven tested crops irrespective of the temporal effect and the highest level of induction of sclerotial population was observed in groundnut and cowpeas (21.81 and 20.06 no. of sclerotia/ $100 \mathrm{~g}$ of soil, respectively) and was statistically at par, whereas, reduction in sclerotial population was observed the highest in napier followed by sorghum and maize plots (Table 1). The sclerotial population in the soil, irrespective of the effect of crop rhizosphere significantly increased steadily up to 60 days after sowing and decline thereafter. However, both sclerotial decay $\%$ and number of dead sclerotia

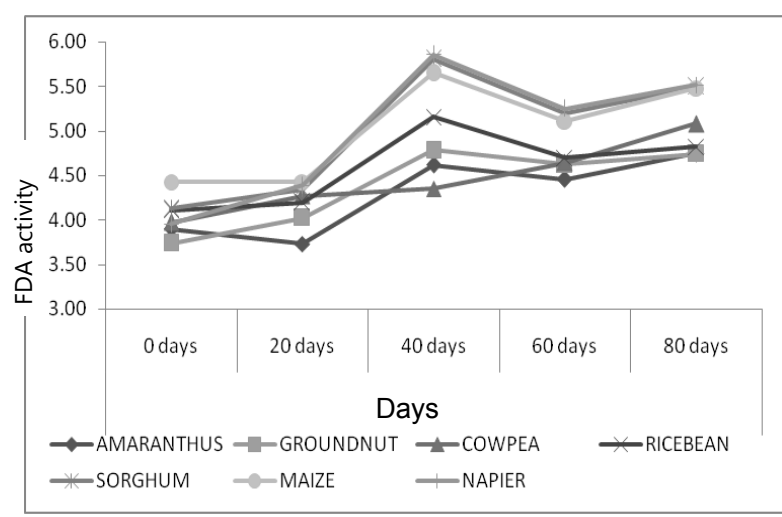

Fig. 6. Temporal variation of FDA hydrolysis activity of various crops under study.

per $100 \mathrm{~g}$ soil also increased with the increasing sclerotial population up to 60 days after sowing but never declined thereafter, resulting ultimate decline in the sclerotial population beyond 60 days after sowing (Fig. 4).

Sclerotial decay: The highest sclerotial decay (\%) was observed in maize (20.32) and was statistically at par with Napier (19.82) and sorghum (18.66) while the lowest sclerotial decay (\%) was observed in ricebean (13.37) which is statistically at par with amaranthus, growndnut and cowpea (Table 1).

Regression analysis: The stepwise multiple regression analysis showed that total microbial activity in terms of FDA hydrolysis and could explain the time course variation in AUDPC and sclerotial population in $68.8 \%$ and $65 \%$ cases, respectively (Eqn. 1 and 2 ).

On the other hand, considering the rhizospheric effect of different crop, it is the total microbial activity in the rhizosphere is the single most important determinant of sclerotial decay (\%) in more than $80 \%$ cases (Fig. 5) while Pearson's correlation analysis showed that besides FDA hydrolysis, there are more than 95\% probability that total bacterial population (40 DAS) has a significant positive role in predicting sclerotial decay percentage in $78.1 \%$ cases $(\mathrm{r}=0.781 \%)$. Paramageetham and Prasada Babu (2012) observed that the soil fungistatic activity of antagonistic bacteria is mainly due to the production of $\mathrm{HCN}$, siderophore and protease enzyme.

$\operatorname{AUDPC}(\mathrm{Y})=7853.45-1499.77(\mathrm{FDA}) ; \mathrm{R}^{2}=0.688$; $\mathrm{R}^{2}$ adj. $=0.626 \quad \ldots \ldots \ldots .$. Eq. 1 ; Sclerotial Population $(\mathrm{Y})=61.5-9.89(\mathrm{FDA}) ; \mathrm{R}^{2}=$ $0.65 ; \mathrm{R}_{\text {adj. }}^{2}=0.58 \quad \ldots \ldots$ Eq. 2

Soil microbiological parameters: Maximum microbial activity and microbial population (in terms of FDA hycirolysis) was observed at 40 days after sowing in all the crops except cowpea and is the only crop which stimulate microbial population only after 60 days after sowing. However, decline in microbial activity was observed towards the maturity stage of the crops (Fig. 6). Time course analysis of FDA indicated that the comparatively higher level of FDA activity is observed 
in majority of the experimental crops during 40-60 days after sowing, while comparatively higher level of FDA was noticed during 40-60 DAS (days after sowing) in napier, maize and sorghum crops as compared to other crops (Fig.7). The poaceous crops have the highest FDA activity than the leguminous and other crops. Importantly, crop rhizospheres influenced microbial population and total microbial activity (in terms of FDA hydrolysis). Enhanced microbial activity and microbial population was observed in napier rhizosphere and total fungal population and pseudomonads population was highest in maize and napier, respectively (Table 1). The total bacteria, actinomycetes and Trichoderma did not vary significantly in response to various crop rhizospheres, nevertheless, have a strong positive correlation with the sclerotial decay (\%).Enzymatic and microbiological parameters, rather than chemical ones, such as FDA activity, microbial biomass, total culturable bacteria, fluorescent pseudomonads and Trichoderma populations were more informative for predicting suppressiveness (Bonanomi et al., 2010; Morsy and El-Korany, 2007; Wright et al., 2016).

After correlation studies with all the microbiological parameters and final sclerotial population to the damping off disease of the test crops, it was observed that final sclerotial population was significantly positively correlated with damping off disease percentage at $1 \%$ level of significance and among the microbiological parameters only FDA was found to be significantly negatively correlated with damping off disease percentage at $5 \%$ level of significance (Table 2, eqn. 1 and 2).

Perusal of the data presented in Table 2 indicated that final sclerotial population was significantly positively correlated with progression of $S$. rolfsii induced damping off (AUDPC) even at 1\% level of significance and among the microbiological parameters, FDA and fluorescent Pseudomonads population at 60 days after sowing was significantly negatively correlated with damping off disease progression (AUDPC) at 5\% level of significance.

In the present study, some of the microbiological parameters showed high correlation within themselves and the independent variables consider here to have some of interdependencies. So, step wise regression was performed to eliminate the parameters having interdependence to find the most important microbiological parameters contributing to the susceptibility/ resistance against $S$. rolfsii induced damping off or collar rot disease. FDA activity was considered to be the most important predictor for conducive/ suppressiveness of soil against $S$. rolfsii in West Bengal. The FDA activity can able to predict the variation of sclerotial population upto $62 \%$ in soil, indicative of soil conducive/ suppressiveness against $S$. rolfsii Thus, from the present study it may be concluded that root exudates of different hosts may influence the microbial population and microbiological parameters of soils that may ultimately directs the soil towards conducive/ suppressiveness against $S$. rolfsii.

\section{ACKNOWLEDGEMENTS}

We thank the NASF-ICAR for providing financial grant for carry out the research work.

\section{REFERENCES}

Bonanomi, G., Antignani, V., Capodilupo, M. and Scala, F. (2010). Identifying the characteristics of organic soil amendments that suppress soilborne plant diseases. Soil Biol Biochem 42: 136-144.

Cook, R.J. and Baker, K.F. (1983). The Na-ture and Practice of Biological Control of Plant Pathogens. APS Press, St. Paul, MN.

Dasgupta, M.K. (1988). Principles of plant pathology. New Delhi: Allied Publisher Ltd. 1040 pp.

Devi, T.R. and Chhetry, G.K.N. (2012). Rhizosphere and non-rhizosphere microbial population dynamics and their effect on wilt causing pathogen of pigeonpea. Int $\mathrm{J}$ Sci Res Pub 2(5):1-4.

Elad, Y. and Chet, I. (1983). Improved selective media for isolation of Trichoderma spp. or Fusarium spp. Phytoparasitica 11(1):55-58.

Ferguson, L. M. and Shew, B.B. (2001). Wheat straw mulch and its impacts on three soilborne pathogens of peanut in microplots. Plant Disease. 85: 661-667.

Fery, R.L. and Dukes Sr., F.D. (2002). Southern blight (Sclerotium rolfsii Sacc.) of cowpea: yield-loss estimates and sources of resistance. Crop Prot. 21: 403 408.

Garren, K.H. (1961). Symposium on Scerotium rolfsii: Control of $S$. rolfsii through cultural practices. Phytopathology. 51:120-124.

Ghosh, P.P., Dutta, S. and Chattopadhyay, A. (2015) Integration of organic and inorganic amendments with native bioagents for bio-intensive management of vascular bacterial wilt on eggplant (Solanum melongena). Ind Phytopathol. 68(1):32-38.

Gupta, S.K., Sharma, A., Shyam, K.R. and Sharma, J.C. (2002). Role of soil temperature and moisture on the development of crown rot (Sclerotium rolfsii) of French bean. Plant Dis. Res. 17: 366-368.

Harinath Naidu (2000). Crossandra - a new host record for Sclerotium rolfsii. Ind Phytopathol 53: 496-497.

Harlapur, S.I. (1988). Studies on some aspects of foot rot to wheat caused by Sclerotium rolfsii Sacc. M.Sc. (Agri) Thesis, University of Agricultural Sciences, Dharwad, 98-99.

Ingale, R.V. and Mayee, C.D. (1986). Efficacy and economics of some management practices of fungal diseases of groundnut. J. Oilseeds Res. 3: 201-204.

Jeffrey, L.S.H. (2008). Isolation, characterization and identification of actinomycetes from agricultural soils at Semongok, Sarawak. Afr J Biotechnol 7:3697-3702.

Kumar, N., Dagla, M. C., Ajay, B. C., Jadon, K. S. and Thirumalaisamy, P. P. (2013). Sclerotium Stem Rot: A Threat to Groundnut Production. Popular Kheti, 1(3): 26-30 
Le, C.N. (2011). Diversity and biological control of Sclerotium rolfsii, causal agent of stem rot of groundnut. $152 \mathrm{pp}$.

Leach, L. D. and Davey, A. E. (1938). Determining the sclerotial population of Scleritium rolfsii by soil analysis and predicting losses of sugar beets on the basis of these analysis. J Agric Res 56:619-631.

Lynch J. M. and Whipps, J. M. (1990). Substrate flow in rhizosphere. Plant soil.129:1-10.

Mayee, C.D. and Datar, V.V. (1988). Diseases of groundnut in the tropics. Review Trop. Pl. Path. 5: 169-198.

Morsy, S.M. and El-Korany, A.E. (2007). Suppression of Damping off and Charcoal-rot of sunflower with composted and non-composted agricultural wastes. Egypt. J. Phytopathol. 35(2):23-38.

Paramageetham, Ch. and Prasada Babu, G. (2012) Antagonistic Activity of Fluorescent Pseudomonads against a Polyphagous Soil Born Plant Pathogen Sclerotium rolfsii. 1:436. doi:10.4172/ scientificreports. 436 .

Schnurer, J. and Rosswall, T. (1982). Fluorescein Diacetate Hydrolysis as a measure of total microbial activity in soil and litter. Appl Environ Microbiol 43(6):12561261.

Singh, A. and Singh, H.B. (2004). Control of collar rot in mint (Mentha sp.) caused by Sclerotium rolfsii using biological means. Curr. Sci. 87: 362-366.

Thiribhubanamala,. G, Rajeswar, E. and Sabitha Doraiswamy (1999). Inoculum levels of Sclerotium rolfsii on the incidence of stem rot in tomato. Madras Agric. J. 86: 334.

USDA (2003). Biological control of Fusarium wilt and other soil-borne pathogenic fungi.Retrieved from http:// www.ars.usda.gov/research/projects/projects.htm? ACCN NO $=406590 \&$ fy $=2003$

Utkhede R. S. and Rahe J. F. (1979). Wet sieving flotation technique for isolation of Sclerotium cepivorum from Muck soil. Phytopathology. 69:295-297.

van Agtmaal, M. (2015). Suppression of soil-borne plant pathogens. $\mathrm{PhD}$ thesis, Wageningen University, Wageningen, NL. Page No.: 11.

Wright, P.J., Falloon, R.E. and Hedderley, D. (2016). A long -term vegetable crop rotation study to determine effects on soil microbial communities and soilborne diseases of potato and onion, New Zealand Journal of Crop and Horticultural Science, DOI: 10.1080/ 01140671. 2016.1229345

Xu, Z.H., Harrington, T.C., Gleason, M.L. and Batzer, J.C. (2008). Phylogenetic placement of plant pathogenic Sclerotium species among teleomorph genera. Mycologia. 102(2): 337-346. 